\title{
Kadastro sonucu orman sayılmayan ağaçlık alanlar: Gölcük orman işletme şefliği örneği
}

\author{
Woodlands not considered as forests trough cadastre: a case study in Golcuk
}

\author{
Hüseyin AYAZ ${ }^{1}$ iD, Uzay KARAHALiL ${ }^{2}$ \\ ${ }^{1}$ Trabzon Üniversitesi, Hukuk Fakültesi, Kamu Hukuku Bölümü, Trabzon, Türkiye \\ ${ }^{2}$ Karadeniz Teknik Üniversitesi, Orman Fakültesi, Trabzon, Türkiye
}

\section{Eser Bilgisi / Article Info}

Araştırma makalesi / Research article

DOI: 10.17474/artvinofd.599497

Sorumlu yazar / Corresponding author

Hüseyin AYAZ

e-mail: hayaz@ktu.edu.tr

Geliş tarihi / Received

31.07.2019

Düzeltme tarihi / Received in revised form

30.09.2019

Kabul Tarihi / Accepted

01.10 .2019

Elektronik erişim / Online available

30.10.2019

\section{Anahtar kelimeler:}

Orman mülkiyeti

Kamulaştırma

Orman alanlarının daraltılmas

Özel orman

\section{Keywords:}

Forest ownership

Nationalization

Forest degradation

Private forest

\section{Özet}

Türkiye'de orman tanımı ve mülkiyeti konularında halen sorunlar yaşanmaktadır. Sosyo-kültürel değişim ve ekonomik gelişmelerin etkisiyle, ülke orman varlığında artışlar yaşansa da yasa değişiklikleri ve yönetsel kararlarla orman ağaçları ile kaplı geniş araziler orman sayılmamaktadır. Bu yaklaşım önemli miktarda orman alanının yasal koruma dışında kalmasına sebep olmaktadır. Yaşanan bu sorunu ortaya koymak ve çözüm önerileri geliştirmek üzere Gölcük Orman İşletme Şefliği örnek alan olarak seçilmiştir. Seçilen alanda, farklı zamanlardaki orman amenajman planı verileri ile arazi kadastrosu sonucu belirlenmiş orman varlığı arasındaki farklııklar, konum ve büyüklük olarak irdelenmiştir. Ulaşılan sonuçlara göre, 1972 ile 2015 yılı arasında orman ağaçları ile kaplı alan \%20 civarında artmıştır. Ancak, arazi kadastrosu sonuçlarına bakıldığında, orman varlığındaki artışın sadece \%20'si miktarında alanın orman varlığına dahil edildiği tespit edilmiştir. Evvelinden beri orman olan veya üzerinde sonradan orman örtüsü oluşan toplam 904.5 hektar arazinin ise kadastro uygulaması sonucunda orman sayılmadığı görülmektedir. Bilimsel ölçütlere göre orman vasfı taşıyan arazilerin orman dışında bırakılmasın önemli sebeplerinden birisi, çok sınırlı haller dışında özel orman mülkiyetine izin vermeyen mevzuattır. Yapılası gereken, evvelinden beri devlete ait olan ormanların dışında kalan, tapulu arazilerde var olan veya sonradan oluşan ormanların mülkiyetine müdahale edilmemesidir. Bu yerler orman sayılmalı, sürekliliği güvenceye alınmalı, sahiplerinin faydalanması için ormancılık teşkilatı yerel çalışanlarının yapacağı faydalanma düzenlemesi ve kontrolü yeterli görülmelidir.

\begin{abstract}
There are still problems in the definition of forest and forest ownership issues in Turkey. Due to sociocultural changes and economic developments, although there is an increase in the forest assets of the country, large areas covered with forest trees are classified as non-forest areas through changes in laws and administrative decisions. While forested land area is on the increase thanks to the developments in technology and better socio-economic life standards, some forested areas have been registered as non-forest areas through changes of laws and administrative decisions. This approach causes a significant amount of forest area to be excluded from legal protection. A pilot area, Gölcük State forest sub district, was selected to evaluate the magnitude of the problem and formulate suggestions. In the study area, forestland area change was determined using forest management plans and land cadaster records. According to forest management plans irrespective of land cadaster, total land area covered with forest trees increased by $20 \%$ between 1972 and 2015. However, according to the forest management plans developed based on land cadaster, the increase in total registered forestland was only $4 \%$. It was observed that a total of 904.5 hectares of land, which had previously been forested or later covered with forest cover, were not considered forest by the cadastral applications and, thus, not included in forest management plans. One of the most important reasons for exclusion of areas from areas that are considered forest from a scientific stand point is the legislation that does not allow private forest ownership except in very limited circumstances. What should be done is not to interfere with the privately owned forested lands that were outside the forests belonging to the state, or that were subsequently formed. These places should be considered as forests and their sustainability should be ensured. Utilization regulation and control by the local forest administration should be considered sufficient for the utilization of the land by their owners.
\end{abstract}

\section{GiRiş}

İlk çağlardan beri farklı amaçlarla tahrip edilmekte olan ormanların kıt kaynak durumuna gelmesi ile birlikte, egemen güçlerin bu kaynak üzerindeki sınırsız yararlanma ve sahiplenmeye müdahale etmeye başladıkları

bilinmektedir. Bu müdahaleler, toplumlara ve zamana göre farklılıklar görülmektedir. Birçok ülkede özel mülkiyete dokunulmadan ormanların sürekliliğinin 
sağlanması için kurallar konulması yoluna gidilirken, Türkiye'nin de aralarında olduğu, Orta ve Doğu Avrupa ülkeleri ile Tanzanya, Nepal gibi birçok ülkede özel mülkiyetteki ormanların tamamına yakını devletleştirmiştir (Sarvasova ve ark. 2015; Kalumanga ve ark. 2018; Baral ve ark. 2019).

Ormanların mülkiyetinin tespiti ve sürekliliğinin sağlanması konusunda Türkiye'deki sürece bakıldığında, ilk kapsamlı yasanın 1937 yılında yürürlüğe konulduğu görülmektedir. Bu tarihten itibaren, yasalar ve anayasalarda, ormanlar milli kaynak olarak görülmüş, devlet mülkiyetinde bulunması gerektiği kabul edilmiş, özel mülkiyete devri yasaklanmış ve herhangi bir şekilde özel mülkiyete konu olan ormanların tamamına yakını da devletleştirilmiştir (Diker 1947; Aksoy 1987; Bingöl 1990). Ancak, bu şekilde ormanların devlet mülkü olarak tespit ve tesciline başlanması, ormanları sahiplenmiş halkın yoğun tepkisine neden olmuş, tepkiler ve eleman yetersizliği orman sınırlamasında kayda değer yol alınmasını engellemiştir (Diker 1947; Kayganacıoğlu ve ark. 1976; Çağlar 1979; Bingöl 1990). Özellikle ülkede var olan tüm ormanların devletleştirildiği 1945 yılının hemen sonrasındaki iki yıl içinde 290000 hektar orman alanı yakılmıştır (Çağlar 1979).

Önceleri halkın istek ve beklentileri dikkate alınmamakla birlikte, 1940 'lı yılların sonlarına doğru çok partili rejime geçişle birlikte bu kez, orman kaynaklarının istismarına sebep olacak kanun değişiklikleri yapılamaya başlanmıştır (Özdönmez ve ark. 1989). Özellikle 1961 yılından sonraki dönemde, anayasalarda da yer verilmiş yasaklar sebebiyle özel mülkiyete devredilmeyen ormanlar gerek orman tanımında değişiklik yapılarak gerekse de önlenemeyen tahrip ve talanlarla orman örtüsü yok edildikten sonra, farklı sebepler oluşturularak orman sayılmamış ve bu şekilde orman sayılmayan alan olarak nitelendirilip özel mülkiyete devredilmeye başlanmıştır. 1950'li yılından 2010 yılına kadar kanun değişikliklerine dayalı olarak, yalnızca kadastro çalışmaları sonucu sebep olunan orman azalmasının 1.1 milyon hektarı aştığı belirtilmektedir (Çağlar 2014).

Ormancılık mevzuatındaki orman varlığı aleyhine değişikliklerden başka, taşınmazların sahip ve sınırlarının belirlendiği kadastro çalışmalarının farklı kurumlar tarafından çeşitli kanunlara göre yapılması da birtakım sorunlara sebep olmuştur (Ayanoğlu 1992). Özellikle, sadece özel mülkiyete konu arazilerin tespitine yönelik tapulama çalışmaları sırasında orman vasfı taşıyan arazilerin bir kısmının şahıslar adına tapulandığı görülmektedir. Arazi fiilen orman olmasına ve mevzuata göre bu yerlerin özel mülkiyete konu edilmesi yasaklanmış bulunmasına rağmen, arazinin vasfı gerçeğe aykırı (tarla, çalılık vb.) gösterilerek kişiler adına tapu kayıtları oluşturulmuştur (Ayaz 2004). Bu uygulamalar arazi kadastrosunun tek elden yürütülmesini sağlayan 1987 tarihli kadastro kanununun uygulanmasına kadar sürmüştür. Orman idaresi de çoğu zaman bu tapulama işlemine karşı duyarsız kalmış, devlet ormanlarının özel mülk olarak tespit ve tesciline karşı itiraz etmemiş, yargı yoluna başvurmamıştır.

Yürürlükteki mevzuat gereğince, hukuka aykırı olarak şahıslar adına tapu kayıtları oluşturulmuş yerlerin, bu usulsüzlüğün tespiti anından itibaren davaya konu edilmesi ve yargı birimleri tarafından bahse konu tapuların iptali gerekir. Özellikle kadastro yenileme çalışmalarında bu tür yerler gündeme gelmekte ve sorun oluşturmaktadır. Mevzuat böyle olmakla birlikte, tapulama çalışması sürecinde müdahale edilmemiş olması ve aradan 50 yılı aşkın süre geçtikten sonra verilmiş tapuların yok sayılması/iptali ciddi tartışmalara/davalara sebep olmaktadır. Bu durumun mülkiyet hakkını kaybetme sıkıntısını yaşayan halkın tapuya güvenini zedelediği ifade edilmekte (Gençay 2016), devlet kurumları tarafından verilmiş tapuların geçerli kabul edilmesi ve şahısların mülkiyet hakkına hiçbir şekilde dokunulmaması gerektiği görüşünü savunanlar bulunmaktadır. Hatta, kişilerin mülkiyetindeki ormanların vasıflarının değiştirilmesine de müdahale edilmemesi gerektiği de öne sürülmektedir (Güneş 2018).

Tapulama sonucu özel mülkiyete konu edilmiş yerlerde, yaklaşık olarak 2008 yılına kadar, malikler aleyhine orman idaresi tarafından açılan tapu iptal davalarının çoğu, oluşturulmuş tapu kayıtlarının dönemin yasalarına aykırı olduğu ve yolsuz tescil niteliği taşıdığı gerekçeleri ile şahıslar aleyhine sonuçlanmıştır. Yıllardır tapulu özel mülk olarak kullanılan arazinin, sahibine hiçbir hak 
tanınmaksızın, devlet ormanı sayılması üzerine, ülkede iç hukuk yolu tüketildikten sonra, bu kararların bir kısmı için Avrupa İnsan Hakları Mahkemesi (AiHM) bünyesinde davalar açılmıştır. AiHM'si, açılan benzer davalarda, Avrupa İnsan Hakları Sözleşmesi, 1 Numaralı Ek Protokol'ün 1. maddesinde düzenlenen mülkiyet hakkının ihlal edildiğine ilişkin süreklilik arz eden mahkûmiyet kararları vermiştir (Ayaz ve İnanç 2009). Devlet tarafından yüklü tazminatlar ödenmek zorunda kalınması sonrasında, 2009 yılından itibaren Yargıtay bu konudaki içtihatlarını değişikliğine gitmiştir. Artık, tapu sicilinin tutulmasından kaynaklanan alacak nedeniyle devlet aleyhine açılan davalarda, TMK m. 1007. maddesi gereğince, devletin kusursuz sorumluluğundan kaynaklanan bir zararının oluştuğuna ve bu zararın tazmininin devletten istenebileceğine karar verilmeye başlanmıştır (Yargıtay 2019).

AiHM tarafından verilen kararlar sonrasında, orman vasfındaki arazilere ait özel mülkiyet belgeleri hakkında yeni düzenlemelere gidildiği görülmektedir. Nitekim, 2012 yılında 6292 sayılı Kanunla yapılan değişiklik sonrasında, Orman Kanunu'nun 2/A ve 2/B maddelerine göre orman sınırları dışına çıkarılan yerlere ait özel mülkiyet belgesi bulunması halinde, bu belgeler geçerli kabul edilecek ve bahse konu yerlere ait sicil kayıtları aynen devam edecek, tapu sicil kayıtları iptal edilmiş olanlar için de eski sahipleri adına sicil kayıtları oluşturularak özel mülkiyet hakkı eski sahibi veya mirasçılarına teslim edilecektir. Bu yasa değişikliğinin "hukuk devleti olmanın bir gereği" olduğu yolunda değerlendirmeler de yapılmaktadır (Gençay 2016).

Çok sayıda kanun değişikliğine gidilmesine rağmen, yürürlükteki mevzuata göre orman vasfında olan, ancak, orman değilmiş gibi gösterilerek şahıslar adına tapu sicil kaydı bulunan arazilerle ilgili mülkiyet ve vasıf sorunu devam etmektedir. Orman örtüsü 1982 tarihinden önce tahrip edilen yerlerde bu arazilerin, satışa konu edilmeyip, Orman Kanunu'nun 2/B maddesi kapsamında sahiplerine bırakılması veya devredilmesi sorunun bir kısmını çözmektedir. Ayrıca, bu uygulamanın orman tahribatını özendirdiği de yadsınamaz bir gerçektir. Anayasa ve ormancılık mevzuatına göre, şahıslar adına tapulu olmakla birlikte, evvelinden beri ve halen orman olan ve çevre parsellerle birlikte orman bütünlüğü oluşturan yerler için tapu iptal davaları açılarak bu yerlerin devlet ormanı olarak tescili gerekmektedir.

Son yıllarda orman idaresi, orman vasfı ve mülkiyeti uyuşmazlıklarının yasalar ve yargısal içtihatlarla, hukukun içinde kalınarak çözülmesi sürecini baltalayan bir yola girmiştir. İare tarafından 2012 tarihli Orman Kadastrosu ve 2/B Uygulama Yönetmeliğinin 19. maddesinde 2013 yılında değişikliğe gidilerek, tapulama çalışması yapılmış yerlerdeki orman kadastrosu uygulamalarında, orman bütünlüğünün parsel bazında değerlendirileceği belirtilmiştir (Resmi Gazete 2012). Diğer bir anlatımla, Anayasa yasalara göre orman sayılan ve Orman Kanunu'nun 2/A ile 2/B kapsamı dışında kalan arazi, şayet eski yıllarda gerçekleştirilmiş tapulama sonucu özel mülk olarak tescil edilmiş ise ve parsel büyüklüğü de 3 hektarı aşmıyorsa, orman vasfı ve bütünlüğü bakımından tartışılmayacak, mülkiyetine ve vasfına dokunulmayacaktır. Bu şekilde, onlarca hektar büyüklüğündeki orman alanı, eylemli durumda da orman ağaçları ile kaplı olmasına rağmen, çok sayıda parsele ayrılarak tapu sicili oluşturulduğu için, orman sayılmamaktadır. Bu nitelendirme, Anayasa ve orman kanunlarındaki orman tanımıyla ve ormanların daraltılamayacağı kuralı ile bağdaşmamaktadır.

Fiilen orman örtüsü ihtiva eden ancak yapılan kadastroya göre şahıslar adına tapulanmış, eylemli durumda da orman vasfı devam eden alanların orman sayılmaması, orman amenajman planlarının yapımında da sorun oluşturmaktadır. Kadastro altlığı kullanılarak yapılan orman amenajman planlarında, eylemli durumda onlarca hektar büyüklüğünde orman bütünlüğü oluşturan, çoğu zaman devlet ormanları ile de bütünlük halinde bulunan bu yerler, ormancılık bilimi ile bağdaşmayacak biçimde, orman dışında bırakılmaktadır. Planlamacılar, eylemli durumda orman ağaçları ihtiva ettiklerini göstermek için de bu yerleri "Kadastroya Göre Orman Dışı Ağaçlık Alan" (KDA) olarak belirtmektedirler. Bu alanlar için "Orman Dışı Ağaçlık Alan” ifadesi de kullanılmaktadır (OGM 2014). Meri mevzuat gereğince bu yerler ormandır. Ancak, idari tasarruf ile orman sınırları dışında bırakılmaktadır. 
Bu çalışmada, orman amenajman planlarında orman vasfında olduğu belirlenmiş yerlerin, Anayasa ve yasalara aykırı biçimde, özel mülkiyet belgelerine dayanılarak orman sayılmaması durumu değerlendirilmiştir. Amenajman planlarında orman olarak gösterilmiş ve orman bütünlüğü içinde bulunan, özel mülkiyete konu edilmiş yerler KDA olarak belirtilmekte ve orman sayılmamaktadır. Orman amenajman planlarına göre orman örtüsü taşıyan ancak KDA olarak ifade edilerek orman varlığı dışında bırakılan bu yerler ele alınarak değerlendirilmiştir. Bunun için, örnek alan olarak seçilmiş bir orman işletme şefliğinde KDA olarak nitelendirilmiş arazinin, tespit edilebilen en eski tarihten itibaren durumu, zaman içindeki vasıf değişiklikleri, konumu, büyüklüğü ve orman varlığı içindeki oranı tespit edilmiştir. Incelemeye konu uygulamanın, fiili orman varlığının tespitine engel oluşturduğu, bahse konu ağaçlık alanların yasal koruma dışında bırakılarak sürekliliğinin tehlikeye atıldığı değerlendirilmektedir.

\section{MATERYAL ve YÖNTEM}

\subsection{Materyal}

Bu çalışmada, konuyla ilgili, Anayasa, yasa ve sair mevzuat ile yüksek yargı kararları kullanıımıştır. Sonrasında, araştırma alanı olarak seçilmiş Sakarya Orman Bölge Müdürlüğü, Gölcük Orman İşletme Müdürlüğü, Gölcük Orman İşletme Şefliğinin, yeri, büyüklüğü, demografik yapısı ile orman varlığı ile değişimine ilişkin veriler derlenmiştir. Ayrıca, örnek olarak seçilen alandaki güncel orman varlığı, kadastro durumu ve bu alan içindeki KDA alanlarını gösterir veriler toplanmıştır. Orman amenajman planı sayısal meşcere haritası ve kadastro haritası çalışmada kullanılan önemli altıklardır (OGM 2015). Çalışma alanı içinde halkın katılımı ile gerçekleştirilmiş toplantılardaki değerlendirmeleri içeren metinlerden de yararlanılmıştır.

\subsection{Yöntem}

Araştırmaya konu alanda ilki 1972 yılında olmak üzere 4 adet orman amenajman planı yapılmıştır. Bu planlardan ikincisi veri karmaşıklığı nedeniyle kullanılamamıştır. Çalışmada, 1972, 2004 ve 2015 yıllarında yapılımış orman amenajman planlarına ait veriler kullanılmıştır. Eski yıllarda bölgeyi kapsar orman kadastrosu olmadığından orman amenajman planlarında "orman" olarak gösterilmiş yerlerin hukuken de orman olduğu kabul edilmiştir. Her üç plan tarihi esas alınarak KDA alanlarının evveliyatı da buna göre değerlendirilmiştir.

Amenajman planlarına ait veriler yapılmış bir çalışma ile kapsamlı biçimde ortaya konulmuştur (Khan 2017). Bu kaynaktan yararlanılarak, bahse konu yıllardaki orman ve orman dışı alanların zaman içindeki değişimi incelenmiştir. Orman amenajman planı meşcere haritası ile kadastro haritaları yardımıyla ihtiyaç duyulan analizlerin yapılabilmesi amacıyla, temin edilen katmanlar üzerinde bazı ön hazırlıklar gerçekleştirilmiştir. Çalışma alanına ait "ncz" uzantılı temin edilen mahalle bazındaki kadastro haritaları, "dwg" formatına dönüştürülmüştür. Oluşturulan bu dosyalar içinde yer alan katmanlar, ArcGIS 10.0 yazılımı yardımıyla "import from cad" komutu ile "features class" formatına aktarılmıştır. Kadastrro haritalarının, orman amenajman planı meşcere haritası ile konumsal olarak uyumlarının sağlanması amacıyla, poligon katmanlarının datumları, "Project" komutu yardımıyla “ED 1950"den WGS'e dönüştürülmüştür. Meşcere tiplerinin bölmeler ile bölünmesi sonrasında oluşan "bölmecik" haritasındaki ayrı poligonlar, "dissolve" komutu yardımıyla meşcere bazında birleştirilmiştir. Mahalle bazında hazırlanan kadastro haritaları ise "merge" komutu yardımıyla işletme şefliğini kapsayacak şekilde tek katmana çevrilmiştir. Sonuçta, nihai karşılaştırmaya uygun katmanlar hazırlanmıştır. Hazırlanan bahse konu katmanlar ile bir taraftan zaman içindeki orman ve diğer arazi kullanımları, mekan ve alan olarak tespit edilmiş, diğer yönden yıllar içindeki arazi kullanım değişiklikleri belirlenmiştir. Kullanılan kadastro altlıkları ile birlikte, özel orman, orman dışına çıkarılmış alanlar ile KDA alanlarının güncel durumu, yersel dağılımı ve evvelindeki niteliği de tespit edilmiştir. Elde edilen sonuçlar, konu hakkındaki mevzuata göre tartışılarak bütüncül bir yaklaşımla değerlendirilmiş ve öneriler geliştirilmiştir.

\subsection{Araştırma alanının tanıtımı}

Araştırma alanı olarak seçilen Gölük Orman İşletme Şefliği $40^{\circ} 43^{\prime} 35^{\prime \prime}-40^{\circ} 36^{\prime} 50^{\prime \prime}$ kuzey enlemleri ile $29^{\circ} 42^{\prime} 28^{\prime \prime}$ - 
2950'47" (ED 1950 UTM ZONE 35N) doğu boylamları arasında kalmaktadır. Planlama birimi, kuzeyde Marmara denizi, doğuda Kadırga Orman İşletme Şefliği, güneyde
Mahmudiye Orman İşletme Şefliği ve batıda Karamürsel Orman İşletme Şefliği ile çevrilidir (Şekil 1).

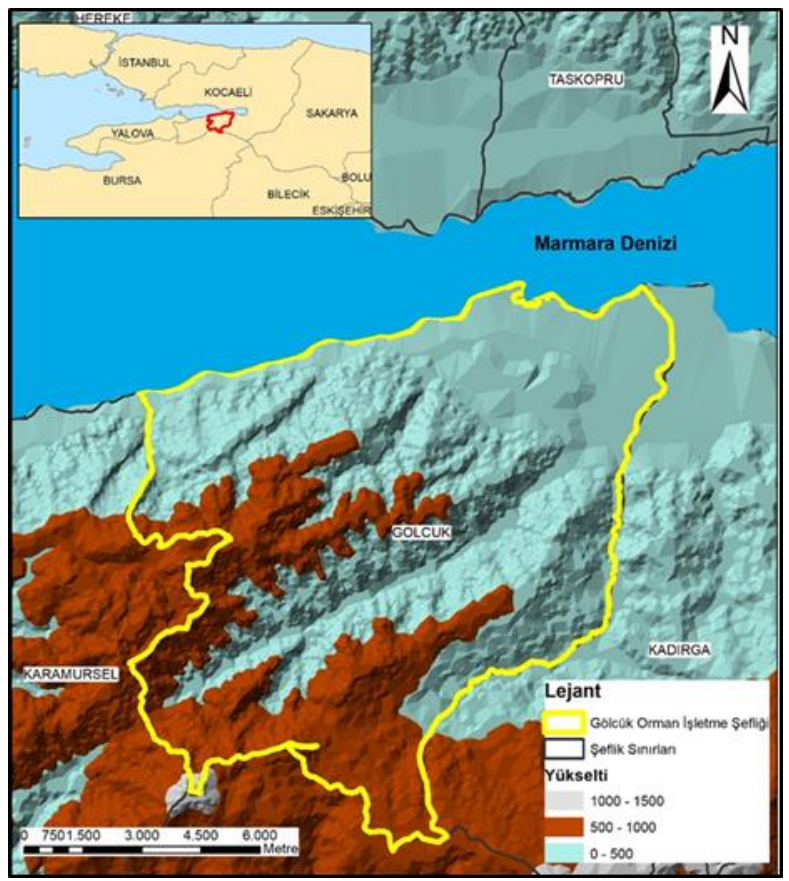

Şekil 1. Araştırma alanının konumsal gösterimi

\section{BULGULAR}

Gölcük Orman İşletme Şefliğinin arazi kullanım durumu ve değişimini içeren üç dönemin amenajman planı alansal verileri bulunmaktadır. Bu veriler yapılmış bir yüksek lisans tezinde de ayrıntılı olarak ortaya konulmuştur (Khan 2017). Bahse konu tezde esas itibariyle orman varlığı ve arazi örtüsündeki değişimler irdelenmiştir. Bu çalışmada ise; bahse konu altıklar kullanılarak, farklı plan dönemlerindeki özel orman durumu ile orman kanununun 2. maddesi $B$ bendine (2/B) göre orman sınırları dışına çıkarılmış alanların miktar ve konumları incelenmiştir. Ayrıca, 2015 yılı itibariyle eylemli durumda orman olmasına rağmen KDA olarak orman sınırları dışında bırakılmış yerler de tespit edilmiştir. Bu yerlerin evveliyatı da sorgulanarak öncesindeki durumları da ayrıntılı olarak tespit edilmiştir.

\subsection{Gölcük Orman İşletme Şefliği Sınırları İçindeki Arazi Varlığı, Niteliği ve Değişikliği}

Gölcük Orman İşletme Şefliği sınırları, alanı ve bu alan içindeki orman varlığı ile değişimi 1972, 2004 ve 2015 tarihli orman amenajman planlarından alınmıştır. Orman amenajman planlardaki orman varlığı hukuken orman sayılan yerlerle farklılık gösterebilir. Ancak, yöntem bölümünde de açıklandığı üzere, araştırma alanında eski orman amenajman planlarının yapıldığı tarihlere ait kadastro çalışması bulunmadığından, amenajman planlarında orman olarak gösterilmiş yerlerin hukuken de orman olduğu varsayılmıştır. Orman amenajman planlarına göre orman işletme şefliğinin toplam alanı 12370.7 hektar olarak tespit edilmiştir. Bu arazinin, 1972 yılı itibari ile 5857.1 hektarı, 2015 yılı itibari ile ise 6280.7 hektarı devlet ormanıdır. 1972 tarihli planda, özel ormanlar ile ilgili bir tespit bulunmadığı gibi henüz Orman Kanunu'nda 1973 tarih ve 1744 sayılı 6831 Sayılı Orman Kanunu'nun Bazı Maddelerinin Değiştirilmesine ve Bu Kanuna 3 Ek Madde ile bir Geçici Madde Eklenmesine Dair Kanun ile değişiklik yapılmamış olduğundan orman sınırları dışına çıkarılmış arazi de yoktur. Üçüncü amenajman planının yapıldığı 2004 yılına gelindiğinde, kanun gereğince 35.5 hektar arazi orman sınırları dışına çıkarılmış olmasına rağmen, devlet ormanının yaklaşık \%25 oranında arttığı ve 7340.4 hektara ulaştığı görülmektedir. Son amenajman planına göre, KDA olarak 
nitelendirilmiş arazi sebebiyle orman varlığının 2004 yılına göre \%15 civarında azalarak 6280.7 hektara gerilediği tespit edilmiştir. Bununla birlikte, 2015 yılı itibariyle devlet ormanının 1972 yılına göre yaklaşık olarak \%7 civarında arttığı görülmektedir. Şeflik sınırları içindeki arazi varlığının yıllar itibariyle durumu ve değişimi aşağıda (Çizelge 1) verilmiştir.

Çizelge 1. Gölcük Orman İşletme Şefliği sınırları içindeki arazi niteliği ve değişimi

\begin{tabular}{|c|c|c|c|c|c|}
\hline & \multicolumn{3}{|c|}{ Yıllara göre alanlar (ha) } & \multicolumn{2}{|c|}{ Arazi niteliği değişimi } \\
\hline & 1972 & 2004 & 2015 & $1972-2004$ & $1972-2015$ \\
\hline Devlet ormanı & 5857.1 & 7340.4 & 6280.7 & +1483.3 & +423.6 \\
\hline Özel orman & - & 244.6 & 301.4 & +244.6 & \\
\hline Orman dışına çıkarılmış alan & - & 35.5 & 35.5 & & \\
\hline KDA alanı & - & - & 904.5 & - & +904.5 \\
\hline Tarım, iskan ve diğer açıklıklar & 6450.6 & 4722.7 & 4821.1 & & \\
\hline Toplam alan & 12307.7 & 12307.7 & 12307.7 & & \\
\hline
\end{tabular}

İlk planlamanın yapıldığı 1972 yılındaki orman amenajman planlarında özel ormanlar ile ilgili bir kayıt yoktur. 2004 yılında ise özel orman miktarı 244.6 hektar olarak tespit edilmiştir. 2015 yılına gelindiğinde ise özel orman alanı bir miktar artarak 301.4 hektara ulaşmıştır. Orman kanununun 2. maddesi B fıkrası uygulaması 2004 yılında tamamlanmış olup toplam 35.5 hektar alan orman sınırları dışına çıkarılmıştır.

Orman ağaçları ile kaplı bulunmasına rağmen KDA olarak nitelendirilerek orman sayılmamış arazi miktarı ise 904.5 hektar büyüklüğündedir. Bu miktar 2015 yılı itibariyle devlete ait orman alanının yaklaşık \%14'üne denktir. Diğer bir anlatımla, KDA uygulamasından vazgeçilmesi halinde orman varlığı yaklaşık \%14 artacaktır. Gölcük Orman İşletme Şefliği sınırları içindeki arazinin kullanım durumu aşağıdaki haritada verilmiştir (Şekil 2).

Harita incelendiğinde, özel ormanların nispeten toplu halde bulunduğu, orman sınırları dışına çıkarılmış araziler ile KDA alanlarının ise çok dağınık halde bulunduğu görülmektedir. Nitekim, İşletme şefliği sınırları içindeki yaklaşık 301 hektar olan özel ormanlar birbirine bitişik olmayan 20 farklı noktada bulunmaktadır. Özel ormanların ortalama büyüklükleri 15 hektar civarındadır. Şeflik dahilindeki özel orman miktarının devlet ormanına oranı ise yaklaşık \%5 seviyesinde olup bu rakam Türkiye ortalamasının (\%1) oldukça üzerindedir.

Gölcük Orman İşletmesi sınırları içinde orman kanununun 2/B maddesi kapsamında orman sınırları dışına çıkartılmış arazi 28 ayrı parça ve 35.5 hektar büyüklüğündedir. Orman sınırları dışına çıkarılmış parsellerin ortalama büyüklüğü 12681 m² $^{2} 1.2$ hektar) olarak tespit edilmiştir. Bu parsellerden en küçüğü $311 \mathrm{~m}^{2}$ ve en büyük parsel ise $52808 \mathrm{~m}^{2}$ olarak belirlenmiştir. Orman dışına çıkarılmış her bir parsel içinde çok sayıda kullanıcı bulunmaktadır. Bu yerler çoğunlukla tarım amaçlı kullanılmaktadır.

KDA alanları çoğunlukla tarım alanları ile orman alanlarının kesişim noktalarında ve çok parçalı, dağınık haldedir. Plan ünitesinde birbirine komşu olmayan 159 ayrı noktada KDA alanı vardır. Bu alanların her bir parçası ortalama $51824 \mathrm{~m}^{2}$ (yaklaşık 5.2 hektar) büyüklüğünde olup parçaların minimum büyüklük $2959 \mathrm{~m}^{2}$ (yaklaşık 0.3 hektar) ve maksimum büyüklük ise $1367472 \mathrm{~m}^{2}$ (136.7 hektar) olarak ölçülmüştür. Her bir parça KDA alanı ortalama üç adet parselden oluşmaktadır. Diğer bir ifade ile her bir parça KDA alanında üç ayrı tapu kaydı bulunmaktadır. 


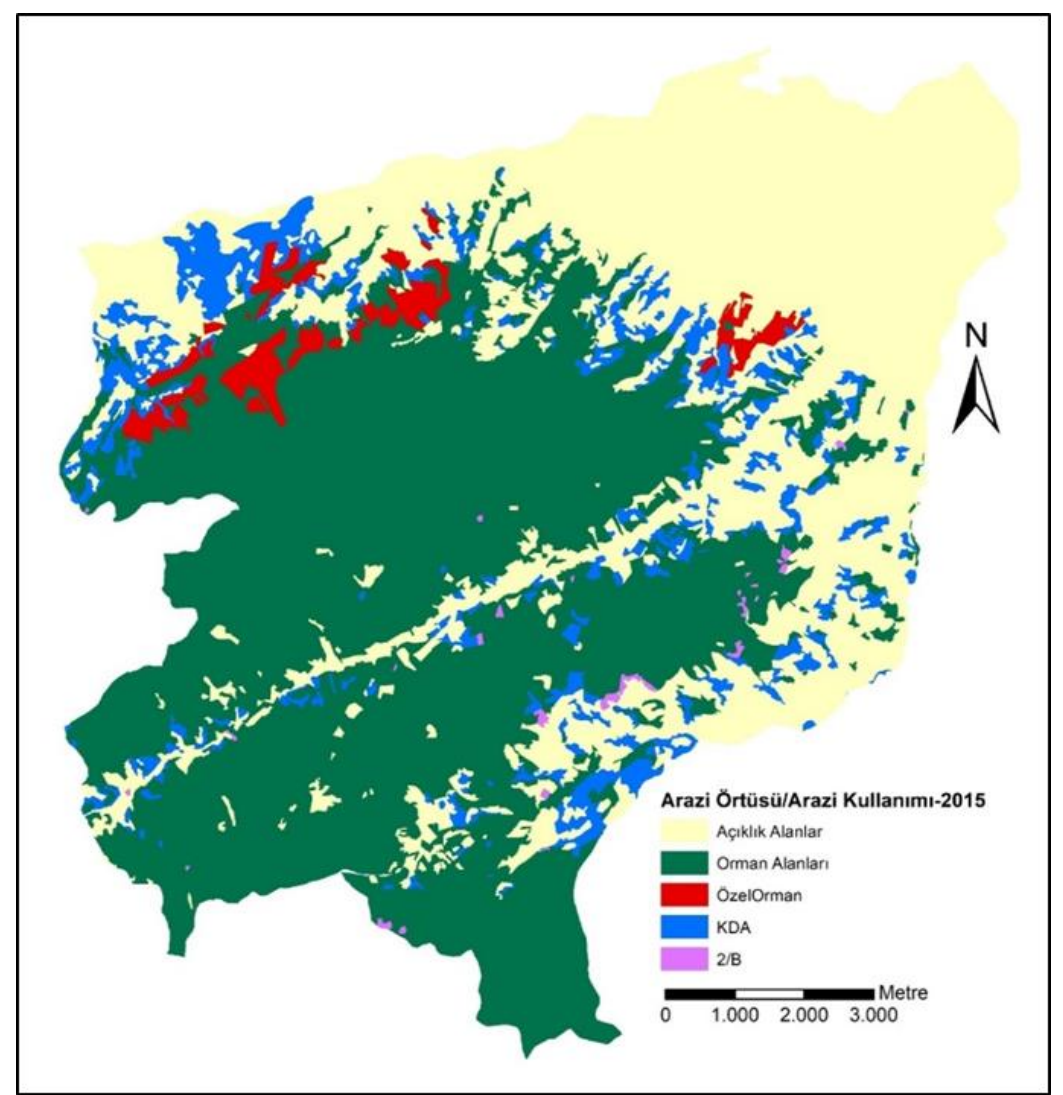

Şekil 2. Gölcük Orman İşletme Şefliğindeki, özel orman, 2/B ve KDA alanlarının dağııımı

\subsection{KDA Alanlarının Geçmişteki Durumu}

Gölcük Orman İşletme şefliği içindeki 15 yerleşim biriminde yapılmış arazi kadastrosunda şahıslar adına tapulanmıs ancak orman amenajman envanterine göre eylemli durumda orman ağaçları ile kaplı arazi büyüklüğü 2015 yılı itibariyle 904.5 hektardır. Şeflik sınırları içindeki arazi vasfı zaman içinde mekansal ve miktar olarak değişikliğe uğratılmıştır. Üç farklı döneme ait amenajman planı verileri ve 1972 ile 2015 tarihleri arasındaki arazi kullanım değişiklikleri incelendiğinde dikkat çekici sonuçlar ortaya çıkmaktadır.
Orman amenajman planlarına göre KDA alanlarının yaklaşık 716 hektarlık kısmı (tüm KDA alanının yaklaşık \%80'i) 1972 yılında açıklık (orman dışı alan) olarak nitelendirilmiş yerler içinde kalmaktadır. KDA alanının 188 hektar civarındaki kısmı (\%20'si) ise 1972 tarihli orman amenajman planında devlet ormanı olarak gösterilmiş arazi içindedir. KDA alanlarının 2004 yılındaki durumu incelendiğinde, bu arazinin yaklaşık 633 hektarının devlet ormanı olarak gösterilmiş arazi içinde kaldığı görülmektedir. Alanın 11 hektarlık kısmı da özel orman içindedir. Geriye kalan yaklaşık 260 hektar alan ise 2004 yılı amenajman planında da orman dışı arazi olarak nitelendirilmiş yerler içinde kalmaktadır.

Çizelge 2. KDA alanlarının evveliyatı

\begin{tabular}{lccc}
\hline \multirow{2}{*}{ KDA alanının evveliyatı } & \multicolumn{2}{c}{ Yıllara göre alanlar (ha) } \\
\hline Devlet ormanı & $\mathbf{1 9 7 2}$ & $\mathbf{2 0 0 4}$ & 2015 Yılı KDA Alanı \\
Özel orman & 188.3 & 633.5 & \\
Orman dışına çıkarılmış alan & - & 11.1 & $\mathbf{9 0 4 . 5}$ \\
Tarım, iskan ve diğer açıklıklar & - & - & 259.9 \\
Toplam alan & 716.3 & $\mathbf{9 0 4 . 5}$ & \\
\hline
\end{tabular}


KDA olarak nitelendirilmiş arazilerin orman amenajman haritalarındaki konumu ve zaman içindeki değişimi konumsal olarak sorgulanmak istenmiştir. Bunun için, araştırma alanındaki 1972 ve 2015 tarihli amenajman planı verileri ile Gölcük Orman İşletme Şefliği içindeki mahallelerin arazi kadastro haritaları çakıştırılarak KDA alanlarının durumu tespit edilmiştir (Şekil 3).

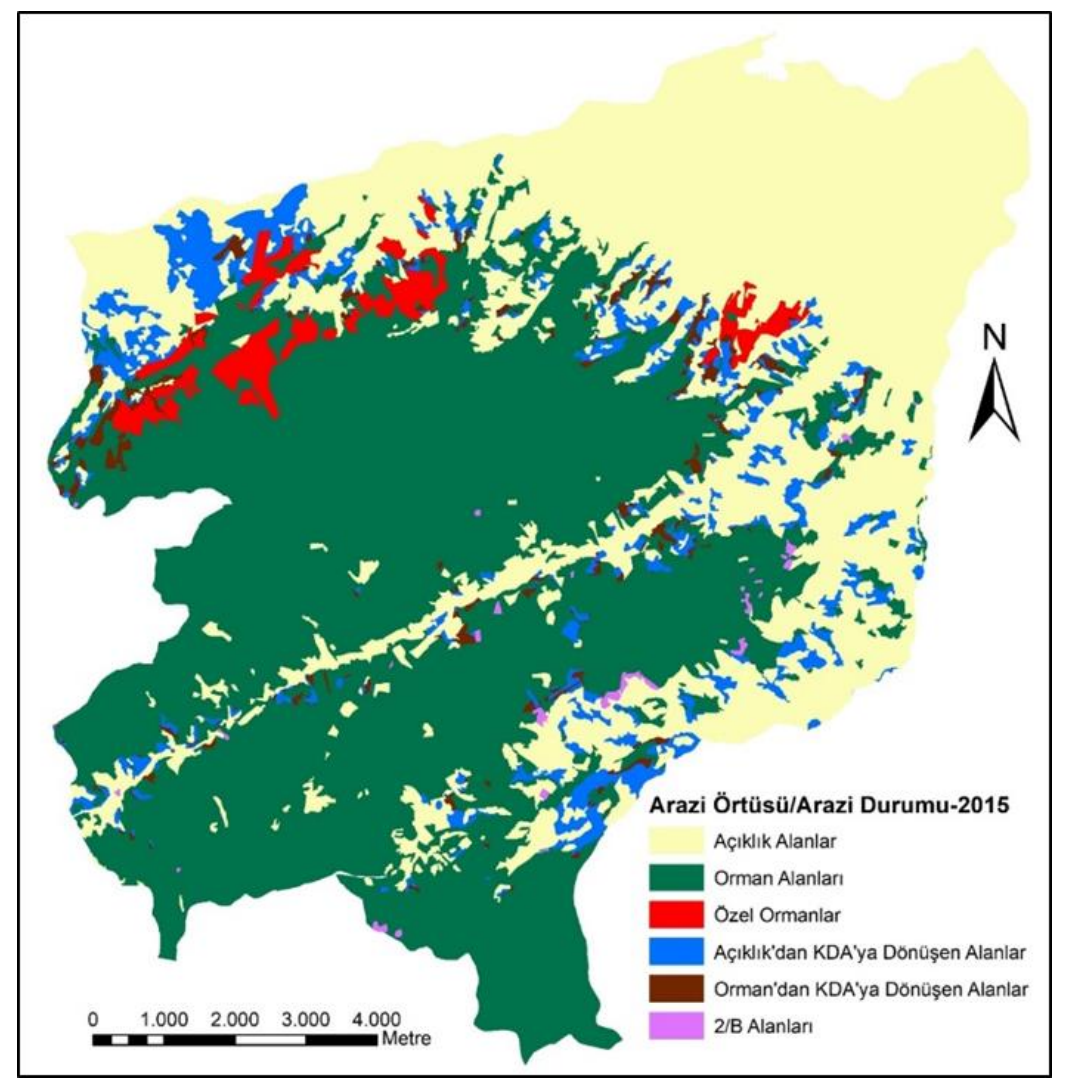

Şekil 3. KDA alanlarının orman amenajman planı haritasındaki konumu

Harita incelendiğinde görüleceği üzere, KDA'lar çoğunlukla devlet ormanı ile orman dışı alanlarının birleştiği yerlerde bulunmaktadır. Kadastro altlı̆̆ı ile birleştirilmiş orman amenajman haritasına göre tüm çevresi devlet ormanı ile çevrili KDA alanı 13 ayrı parça halinde olup bu arazilerin toplam büyüklüğü 20.4 hektar olarak belirlenmiştir. Bu parçaların tamamına yakını 1972 ve 2004 tarihli amenajman haritalarında orman olarak tespit edilmiş yerler içindedir.

\section{TARTIŞMA ve SONUÇ}

Türkiye ormancılığı, orman varlığının tespiti ve yasal güvenceye kavuşturulması konusunda sorunlu bir geçmişe sahiptir. Anayasa ve yasalara göre özel mülkiyet iddiaları reddedilmekte olup orman varlı̆ı̆ın \%99.9'u devlete aittir. Özel mülkiyette bulunan ormanların tamamına yakını devletleşmiş olmakla birlikte, halkın ormanların bir kısmı üzerindeki mülkiyet iddiası halen sürmektedir. Tapuya dayalı sahiplik iddiaları, Doğu Karadeniz Bölgesinde orman varlığının \%5'i civarındadır (Ayaz 2004). Türkiye ile yaklaşık aynı dönemlerde devletleştirmenin yaşandığı Balkan ülkelerinin birçoğunda orman mülkiyet sorunu, devletleştirilmiş ormanların eski sahipleri ve mirasçılarına iadesi yoluyla çözümlenmeye çalışımaktadır (Sarvasova ve ark. 2015). Sürece ilişkin olarak, özel mülkiyete devredilen ormanlar üzerindeki devlet kontrolünün zayıfladığı yönünde eleştiriler yapılmakta, hatta bu uygulamaların ormanların tahribine sebep olduğuna ilişkin tespitler de bulunmaktadır (Whiteman ve ark. 2015). Ülkemizde ise Anayasa ve yasalar gereğince devletleştirilmiş ormanların eski sahiplerine iadesi mümkün değildir. Türkiye'de ormanlar üzerindeki sahiplik iddiaları, bilimsel ölçütlere aykırı yasal düzenlemelerle, ya orman sayılmayarak veya orman örtüsünün tahribi sonrasında orman sınırları dışına 
çıkarılarak özel mülkiyete konu edilmektedir. Öyle ki; özel orman miktarı yaklaşık 10000 hektar iken, orman örtüsü tahrip edildiği için orman sınırları dışına çıkarılmış alan özel orman miktarının 50 katı büyüklüğe ulaşmıştır. Son yıllarda, yasa değişikliklerinin de ötesine geçilerek, yürütme erkinin idari tasarrufu ile de orman sayılmayan alanlar tespit edilmeye başlanmıştır. Bunlardan birisi de KDA alanlarıdır.

Gölcük Orman İşletme Şefliği sınırları içindeki devlet ormanının \%14'ü kadar arazi fiilen orman ağaçları ile kaplı olmasına rağmen KDA niteliği ile orman sınırları dışında bırakıımıştır. KDA alanının miktarı, 1970 yılından itibaren orman kanununun 2/B bendine göre orman sınırları dışına çıkarılmış arazinin yaklaşık 25 katı ve özel orman miktarının da 3 katı büyüklüktedir. KDA uygulaması sonucunda orman ağaçları ile kaplı, oldukça geniş bir arazi, ormancılık mevzuatı kapsamı dışında bırakılmıştır. Kanuni koruma dışında bırakılan bu arazi üzerindeki ağaçlar, Orman Kanunu'nun 116. Maddesi kapsamında tamamen kesilerek yok edilebilir ve arazi başka amaçlara kullanılabilir.

Yasa ve idari kararlarla orman alanları daraltılıyor olsa da 1980 'li yılların ortalarından itibaren orman varlığında artış olduğu da bilinmektedir. Bu artış, kırsal alandaki nüfusun azalması ve eskinde tarım, mera veya yerleşim amacıyla kullanılan alanların terki sonucunda bu arazilerin doğal olarak orman örtüsü ile kaplanmasına dayalıdır. Türkiye'de genelinde 1973 yılı itibariyle orman alanı 20.2 milyon hektar iken \%1 civarında artışla 2015 yılında 22.7 milyon hektara ulaşmıştır (OGM 2019). Kırsal kesimden yoğun göçlerin yaşandığı birçok yerde ise ormanlaşma oranı Türkiye ortalamasının çok üzerine çıkmaktadır (Bayramoğlu ve Kadıoğulları 2018). Araştırma alanında da orman varlığı aleyhine uygulamalara rağmen 1972 ile 2015 yılları arasında orman alanı artışı \%7 civarındadır. Gölcük ilçesinde nüfus varlığı ve değişimine bakıldığında, 1970 yılında topla nüfus 51000 kişin olup nüfusun \%41'i (yaklaşık 21000 kişi) kırsal kesimde yaşarken 2012 yılı itibariyle ilçe nüfusu yaklaşık 144000 kişi olup bu nüfusun \%4'ü (yaklaşık 5800 kişi) kırsal kesimde yaşamaktadır (TÜik 2019). 2012 yılında kanun değişikliği sonucu birçok ilde kent ve kır nüfusu ayrımı yapılmadığından sonraki tarihlere ait veri yoktur.
Araştırma alanında 2015 yılı itibariyle, 1972 yılına göre orman varlı̆ı̆ıda artış görülmekle birlikte, 2004 yılı ile 2015 yılı arasındaki zaman diliminde yaklaşık 1060 hektar azalma vardır. Bu azalmanın en önemli sebebi, orman ağaçları ile kaplı ve ilmen orman vasfında olan 904.5 hektar arazinin KDA olarak ayrılması ve orman sayılmamasıdır. Diğer taraftan, KDA olarak nitelendirilmiş arazinin yaklaşık \%80'inin 1972 yılındaki orman amenajman planı haritasına göre orman dışı alan olduğu da tespit edilmiştir. Tüm bu veriler, Türkiye'de orman varlığı ve sürekliliğinin sosyal gelişme ve değişimlerden etkilenmekte olduğunu ve henüz sağlıklı bir yapıya kavuşturulamadığını göstermektedir.

Orman amenajman planı yapımı sürecinde halkın katılımı toplantıları gerçekleştirilmiştir. Bu toplantılarda, orman mevzuatı ve ormancılık uygulamalar hakkında yoğun eleştiriler yapılmıştır. Devlet ormanlarına yönelik mülkiyet uyuşmazlıklarının yanı sıra kestane meyvesinden yararlanma ve 244.6 hektar büyüklügündeki özel ormanların, tespiti, yönetilmesi ve işletilmesinde de sorunlar yaşanmaktadır. Zaman içinde çok sayıda hissedarı oluşan özel ormanlar kayda değer miktarda ekonomik gelir sağlamadığından yönetilememekte, sorumlu müdür atanamamakta, işletme planları yapılamamaktadır. Bu konuda yakınmalar görülmekle birlikte, sahipli ağaçlık alanların orman sayılmayarak sahiplerine bırakılması konusunda ise herhangi bir eleştiri yoktur.

\section{5. ÖNERILER}

Farklı tarihlerde özel kişiler adına mülkiyet belgesi düzenlenmiş arazilerin bir kısmı, kaydın oluşturulduğu tarihte de orman ve mülkiyet belgesinin verilmesi hukuka aykırı iken bir kısım alanlar ise orman sayılmayan yerlerdir. Hangi halde olursa olsun, devlet tarafından verilmiş ve sicil kaydı bulunan mülkiyet belgelerinin yok sayılması hukuk devleti için kabul edilebilir bir durum değildir. Nitekim, mülkiyet hakkına müdahale sayılan uygulamalar sebebiyle AiHM kararları doğrultusunda önemli miktarlarda tazminat ödenmek durumunda kalındığı da bilinmektedir. Ancak, onlarca hektarlık bütünlük oluşturan (araştırma alanında büyüklüğü 136.7 hektar olan tek parça KDA vardır) orman ağaçları ile kaplı 
alanların orman sayılmaması da bilim ve fenne aykırıdır. Bu alanlar için, taşınmazların devlet ormanı bağlantısı, ekosistem bütünlüğü ile sahiplerinin istek ve beklentileri dikkate alınarak üç farklı yoldan biri tercih edilebilir.

İzlenebilecek yollar;

i) Tamamen devlet ormanları içinde kalan, bu ormanlar ile bütünlük halinde olup bu ormanların sürekliliği ve işletilmesinde öneme sahip yerler kamulaştırılabilir. Araştırma alanındaki KDA'ların \%2'si bu nitelikte görülmüştür.

ii) Devlet ormanına bitişik ancak orman işletmeciliğin bakımından sorun oluşturmayacak tapulu ağaçlık alanlar, sahiplerinin de görüşleri alınarak, kamulaştırılabileceği gibi, yerel orman teşkilatı tarafından parsel bazında hazırlanacak basit planlar ile sahiplerinin yararlanmasına bırakılabilir. Bu durumda, orman örtüsünün sürekliğini idare tarafından kontrol edilmeli ve ilgili parsellerin tapu siciline de kayıt düşülmelidir.

iii) Orman sınırları dışında bulunan ve evveliyatı da orman olmayan arazi üzerindeki orman örtüsünün devamı için yine yerel orman idaresi görevlileri tarafından basit faydalanma planı yapılabilir. Bu nitelikteki yerler üzerindeki orman ağaçlarının sürekliliğinin sağlanması için arazi vergisi alınmaması vb. teşvikler de uygulanarak halk özendirilebilir.

Ortaya konulan bu öneriler, konu hakkında fikir üreten diğer kişilerin ve muhatap arazi sahiplerinin görüşleriyle daha da zenginleştirilip toplum ve şahıslar için daha faydalı hale getirilebilir.

\section{KAYNAKLAR}

Aksoy M (1987) Anayasalarımız ve Ormanların Korunması. Cumhuriyet Dönemi Ormancılığımızda 3116 Sayılı Orman Yasası ve Sonrası Sempozyumu. Türkiye Ormancılar Derneği Yayınları No: 10, Ankara

Ayanoğlu S (1992) Genel kadastro orman kadastrosu ilişkileri üzerinde incelemeler. İstanbul Üniversitesi Orman Fakültesi Dergisi 42 B: 34, 79-91

Ayaz H (2004) Türkiye Ormancılı̆ı̆nda 4785 Sayılı Yasa'nın Uygulanması ve Sonuçları Üzerine Bir Araştırma (Doğu Karadeniz Bölgesi Örneği). Karadeniz Teknik Üniversitesi Fen Bilimleri Enstitüsü Doktora Tezi, Trabzon, $145 \mathrm{~s}$

Ayaz H, İnanç S (2009) Türkiye'de Özel Ormanlar. Ormancllıkta SosyoEkonomik Sorunlar Kongresi. Isparta, Bildiriler Kitabı, 55-64
Baral S, Meilby H, Chhetri BBK (2019) The contested role of management plans in improving forest conditions in Nepal's community forests. International Forestry Review 21:1, 37-50

Bayramoglu MM, Kadiogullari Al (2018) Analysis of Land Use Change and Forestation in Response to Demographic Movement and Reduction of Forest Crime. Eurasia Journal of Mathematics Science and Technology Education 14:1, 225-238.

Bingöl iH (1990) Geçmişten-Günümüze Ormanlarımı ve Ormancılı̆ıımız. Ormancılık Eğitim Vakfı Yayın No: 4, Matbaa Teknisyenleri Basımevi, İstanbul, $144 \mathrm{~s}$

Çağlar Y (1979). Türkiye'de Ormancılık Politikası (Dün). Çağlar Matbaası, Ankara, $463 \mathrm{~s}$.

Çağlar Y (2014) Hukuksal Kıskaçtaki Ormanlar ve Ormancılık (seçme Tartışmalar). Türkiye Barolar Birliği Yayınları: 209, 978-605-531699-0, Şen Matbaası, Ankara, $388 \mathrm{~s}$

Diker M (1947) Türkiye'de Ormancılık Dün-Bugün-Yarın. T.C. Tarım Bakanlığı OGM Yayınları, Sayı: 61, Akın Matbaası, Ankara, $132 \mathrm{~s}$

Resmi Gazete (2012) Orman Kadastrosu ve 2/B Uygulama Yönetmeliği. Tarih: 20.11.2012, Sayı: 28473, Ankara

Gençay G (2016) Orman sınırları içinde tapu iptali kararlarının mülkiyet hakkını ihlal etmesi sorunu. İstanbul Üniversitesi Orman Fakültesi Dergisi 66:1, 75-89

Güneş Y (2018) Orman ve Arazi Uyuşmazlıkları, On iki levha Yayıncılık A S.. ISBN 978-605-152-795-6, istanbul, $387 \mathrm{~s}$

Kalumanga E, Olwig MF, Brockington D, Mwamfuge A (2018) Partnerships and Governance in Forest Management in Tanzania: Historical and Current Perspectives. NEPSUS Working Paper 2018/1, Frederiksberg, Denmark, 31 s

Kayganacıoğlu MR, Renda N, Onursan G (1976) Gerekçeli-Açıklamalıİçtihatlı Orman Kanunu İlgili Mevzuat. Olgaç Matbaası, Ankara, $1195 \mathrm{~s}$

Khan S.I., (2017) Exploring the Spatiotemporal Dynamics of Gölcük Planning Unit Over 43 Years And Implications of International Conventıons to Management Planning Approach. Karadeniz Teknik Üniversitesi Fen Bilimleri Enstitüsü Yüksek Lisans Tezi, Trabzon, 84

OGM (2014) Ekosistem Tabanlı Fonksiyonel Orman Amenajman Planlarının Düzenlenmesine Ait Usul ve Esaslar. Tebliğ No: 299, Orman Genel Müdürlüğü Orman İdaresi ve Planlama Dairesi Başkanlığı, Ankara, $227 \mathrm{~s}$.

OGM (2015) Gölcük Orman Işletme Şefliği Orman Amenajman Planı, Orman Genel Müdürlügü, Ankara, 269 p. OGM (2019) https://www.ogm.gov.tr/Sayfalar/Ormanlarimiz/TurkiyeOrmanVa rligi.aspx. 04.07.2019

Özdönmez M, İstanbullu T, Akesen A (1989) Ormancılık Politikası. İstanbul Üniversitesi Orman Fakültesi Yayınları, i.Ü. Yayın No:3553, O.F. Yayın No: 401, 301, İstanbul, 1475 s

Sarvasova Z, Zivojinovic I, Weiss G, Dobsinska Z, Dragoi M, Gal J, Jarsky V, Mizaraite D, Pollumae P, Salka J, Schiberna E, Sisak L, Wolfslehner B, Zalite Z, Zalitis T (2015) Forest Owners Associations in the Central and Eastern European Region. Small-Scale Forestry $14: 2,217-232$

TÜiK (2019) Türkiye İstatistik Enstitüsü, Online Veri Tabanları. http://tuik.gov.tr/Start.do. 7 Haziran 2019 tarihinde erişilmiştir.

Whiteman A, Wickramasinghe A, Pina L (2015) Global trends in forest ownership, public income and expenditure on forestry and forestry employment. Forest Ecology and Management 352: 99108

Yargıtay (2019) Yargıtay Hukuk Genel Kurulu Kararı. Avrupa İnsan Hakları Sözleşmesi Devletin Sorumluluğu Mülkiyet Hakkı Tapu Sicilinin Tutulması Yargı Yolu, Içtihat Metni, https://www.kararara.com/forum/viewtopic. php?f $=193 \& \mathrm{t}=3275$ 0.26.05.2019 